\title{
The Investor-EU/Member State(s) Arbitration Mechanism after the Lisbon Treaty: Allocating Financial Responsibility between the EU and its Member States*
}

\author{
By Federica CRISTANi**
}

\begin{abstract}
Questions arise as to what will happen when a foreign investor sues a Member State or even the EU, given the new European Union (EU) competence over foreign direct investment (FDI) from the Lisbon Treaty, Articles 206-207 of the Treaty on the Functioning of the European Union (TFEU). In particular, financial responsibility of the EU resulting from an investor-state arbitration is now becoming a politically sensitive topic, particularly regarding the on-going negotiations between EU and third countries for the conclusion of investmentrelated international agreements. While the EU bears, in principle, international responsibility for the breach of any provision to which it is bound under international law, it is possible, under EU law, to provide for the allocation of financial responsibility between the EU and its Member States. This paper analyses the recent EU Regulation on financial responsibility in investor-State arbitration, putting it in the broader framework of the creation of an EU investment policy and the on-going negotiations between the EU and third countries for the conclusion of investment-related international agreements.
\end{abstract}

Keywords: foreign direct investment, EU investment policy, investor-State arbitration, financial responsibility, ius standi

\section{THE NEW EU'S EXCLUSIVE COMPETENCE IN FDI: DESIGNING A EU INVESTMENT POLICY AFTER LISBON}

Foreign direct investment (FDI) has been traditionally protected at the international level as well as at the national level. The notion of "investment" and "investor" are not clearly and consistently defined under international investment law. In general, private persons, State corporations, international organizations or mixed enterprises may be "investors" under international investment law. ${ }^{1}$ Currently, international investment instruments (in particular investment protection treaties) generally adopt a broad definition of "investment", which is normally linked to the objects and purposes of the treaty itself. However, it is possible to elaborate a concept of "investment" by taking into account the ICSID case law that has dealt with this issue. An ICSID leading case is the Salini case ${ }^{2}$ and the resulting Salini test ${ }^{3}$

* A previous version of the paper was presented at the International Workshop on "The Autonomy of EU Law from the Perspective of International Judicial Bodies: A Mixed Blessing?" organized by the Hungarian Academy of Sciences, Centre of Social Sciences, Institute for Legal Studies and the Corvinus University of Budapest, Faculty of Social Sciences, Institute of International Studies on 1 October 2015. The author is grateful to all the participants at the international workshop for the fruitful discussions. The author is also very grateful to Prof. Attila Tanzi and to Prof. Enrico Milano for invaluable comments and suggestions on previous drafts of the paper.

** Research Fellow at the Institute for Legal Studies of the Hungarian Academy of Sciences Centre for Social Sciences and Post-doctoral Fellow at the Faculty of Law and Political Sciences of the Pázmány Péter Catholic University, Budapest. E-mail: Cristani.Federica@tk.mta.hu

1 Salacuse (2010) 23.

2 Salini Costruttori SPA and Italstrade SPA v. Marocco, ICSID Case ARB/00/4, Decision on Jurisdiction, 23 July 2001.

3 Salini Costruttori SPA and Italstrade SPA v. Marocco, ICSID Case ARB/00/4, Decision on Jurisdiction, 23 July 2001, para 52. 
in order to verify if a certain operation can be defined as an international investment. This test must show that an "investment" must have a certain duration, with a certain regularity of profit and return. Moreover, there must be an element of risk on both sides, the commitment involved must be substantial and the operation should be significant for the host State's development. This test has then been applied by several tribunals. ${ }^{4}$

There have been also initiatives, starting in the 1980s, at the regional level to promote and protect FDI. One of the earliest regional agreements was the 1981 Unified Agreement for the Investment of Arab Capital in the Arab States in the framework of the League of the Arab States. Other regional investment agreements include the 1987 Agreement among the Government of Brunei Darussalam, the Republic of Indonesia, Malaysia, the Republic of Philippines, the Republic of Singapore and the Kingdom of Thailand for the Promotion and Protection of Investments (ASEAN Agreement for the Promotion and Protection of Investments of 1987) and, in the framework of the Common Market of the Southern Cone, the 1991 Treaty of Asuncion between Argentina, Brazil, Paraguay and Uruguay. Another regional agreement within African countries is the 1993 Common Market for Eastern and Southern Africa (COMESA), which is one of the largest trading blocks in Africa. The 1992 North American Free Trade Agreement (NAFTA) between the United States, Canada and Mexico is should be mentioned, in particular its Chapter 11, which can be considered as an investment treaty on its own. ${ }^{5}$

These initiatives are coupled with customary international rules including the minimum standard of treatment, the fair and equitable treatment and full protection and security, and bilateral investment treaties (BITs) between States aimed at promoting and protecting FDI. Moreover, states have their own domestic regulation relating to investment protection. $^{6}$

The European Union (EU) is a unique in the realm of regional organizations and its shaping increasingly impacts up on the application of international investment law in Europe. ${ }^{7}$ In particular, the EU legislation indirectly offers substantial protection for foreign investment. Investment is a cross-border activity, which triggers capital flow and links investors to the host states as well as their home countries resulting in the free movement of persons and capital and the freedom of establishment coming into question. The relevant case law has explicitly set forth that the decisive factor for granting protection under the freedom of establishment necessarily requires a definite influence or control of the company's decisions and its activities whilst allowing the investor to participate in the management of the company involves the free movement of capital. ${ }^{8}$

${ }^{4}$ See Juillard (1994) 24 for comments.

5 For a comment, see Salacuse (2010) 98.

${ }^{6}$ For a general overview of international investment law and principles, see among others, Sornarajah (2004) and Dolzer (2012).

7 The initial treaty establishing the European Economic Community was in 1957, then amended by the 1986 Single European Act, followed by the Treaty on European Union (1992). The latter Treaty changed the name of the European Economic Community to 'the European Community'. After that, there have been two main Treaties, the Treaty establishing the European Community and the Treaty on European Union. These Treaties have been subject to many amendments since 1992, in 1997 (the Treaty of Amsterdam), in 2001 (the Treaty of Nice) and finally in 2009 (the Treaty of Lisbon).

8 See for all, European Court of Justice, Centros Ltd v. Erhvervsog Selskabsstyrelsen, Case C-212/97 (1999) ECR I-1459. 
Moreover, Article 18 TFEU abolishes the discrimination on grounds of nationality, which certainly applies also to foreign investors. Despite this indirect protection for foreign investment, there is a legitimate expectation for further harmonization. ${ }^{9}$

The Lisbon Treaty, in force since 1 December 2009, has added FDI to the exclusive common commercial policy (CCP) of the EU which has now the authority to conclude international investment agreements with third countries. ${ }^{10}$ In particular, Article 206 of the Treaty on the Functioning of the European Union (TFEU), dealing with CCP, establishes that "[...] the Union shall contribute, in the common interest, to [...] the progressive abolition of restrictions on $[\ldots]$ foreign direct investment $[\ldots]$ ".

The addition of the words "foreign direct investment" in Article 207 of the TFEU triggered a fierce debate regarding the scope of the new competence. It raised, in particular, questions such as whether portfolio investments are also covered by the competence and the concomitant issue of whether the new treaties will be concluded as mixed agreements. ${ }^{11}$ It is expected that the European Court of Justice will have an authoritative saying on this issue in the forthcoming Advisory Opinion requested by the European Commission on the competence of the EU to conclude the Free Trade Agreement with Singapore. ${ }^{12}$

This may pose some problems as to the applicable regime for the existing bilateral investment treaties (BITs) concluded by Member States with third countries. This will become an issue of major relevance in global international investment law as EU Member States represent the main users of BITs. ${ }^{13}$

The European Commission has adopted a Communication in $2010,{ }^{14}$ stating that the EU must develop an international investment policy in order to increase EU competitiveness and contribute to the objectives of smart, sustainable and inclusive growth, as set out in the Europe 2020 Strategy. ${ }^{15}$ However, to date, the EU has not defined a clear investment policy. Future EU investment policy will certainly promote European values. Articles 206 and 207 TFEU call on the EU to contribute to a harmonious development and liberalization of world trade, Article 205 TFEU states that the common commercial policy should be guided by the general principles of the EU's external action, including promotion of democracy, the rule of law, further the respect of human rights and contribute to sustainable economic, social and environmental development, as elaborated in Title V, Chapter I TEU. ${ }^{16}$

In the "Fact Sheet. Investment Protection and Investor-to-State Dispute Settlement in EU Agreements" the Commission has highlighted that the definition of a European investment policy requires clarification with respect to investment protection rules in existing BITs in force for EU Member States, particularly in connection with the pursuit of

9 See Lavranos (2010) 409 for a comment.

${ }^{10}$ For a first and general analysis see, among others, Reinisch (2014) 111-157.

11 For some references on this debate, see, among others, Bungenberg (2011) and recently Titi (2015) 641.

12 See more in detail in point 3 of this paper.

13 EU Member States are among the pioneer States in BIT practice (first BIT signed by Germany with Pakistan in 1959 - information from Directorate-General for Trade of the European Commission, available at $<$ http://trade.ec.europa.eu $>$ accessed 9 February 2016).

14 Towards a comprehensive European international investment policy, $\operatorname{COM}(2010)$, 7 July 2010, 343 final, 2 .

15 European Commission's Communication, Europe 2020: a Strategy for Smart, Sustainable and Inclusive growth, $\operatorname{COM}(2010), 3$ March 2010, 2020.

16 For a comment, see Calamita (2012) 301. 
legitimate public policy objectives and the concept of fair and equitable treatment. ${ }^{17}$ Some key investment protection provisions are unclear and the way they are drafted has led to claims that such provisions do undermine the ability of States to regulate in the public interest. For example, many investment agreements in force do not specify the exact meaning and scope of key substantive standards, such as "indirect expropriation" or "fair and equitable treatment", precisely the issues under which investors bring the most claims. The Commission has already pointed to Philip Morris' case against Australia and Vattenfall's case against Germany as examples that raise this concern. ${ }^{18}$

The Commission submitted a proposal for a Regulation, together with its Communication of 7 July 2010, on transitional arrangements for existing BITs of the Member States with third countries, ${ }^{19}$ which finally came into force in December 2012. ${ }^{20}$ The latter grants legal security to the existing BITs between Member States and third countries and allows the European Commission to authorize Member States to open formal negotiations with a third country to amend or conclude a BIT. ${ }^{21}$ This means that almost 1200 BITs concluded by EU Member States will be in force until they are replaced by EU agreements. ${ }^{22}$ The time-frame period should be considered for each BIT i.e. 10 years for the Czech Republic-China BIT and 5 years for The Netherlands-China BIT. ${ }^{23}$ Regarding intraEU BITs, the Commission has requested several times that EU member States stop concluding intra-EU BITs and to terminate those already in force. On $18^{\text {th }}$ June 2015 , the Commission has started infringement proceedings against five member States to terminate intra-EU BITs (Austria, Romania, Sweden, The Netherlands and Slovakia). ${ }^{24}$

At the same time, the EU may start negotiations for the conclusion of international treaties on investment, ${ }^{25}$ either in the form of free trade agreements (FTAs) with chapters on

17 See European Commission, Fact Sheet. Investment Protection and Investor-to-State Dispute Settlement in EU Agreements (March 2014) 1-2 and the paper prepared by the Commission on Investor-to-State Dispute Settlement (ISDS). Some facts and figures (12 March 2015). All documents available at the official DG Trade's website $<$ http://trade.ec.europa.eu $>$ accessed 9 February 2016

18 European Commission, Fact Sheet. Investment Protection and Investor-to-State Dispute Settlement in EU Agreements (November 2013) 5. For a comment on the development of a EU international investment policy see Titi (2015) 657.

19 European Commission, Proposal for a Regulation of the European Parliament and of the Council establishing transitional arrangements for bilateral investment agreements between Member States and third countries, $\operatorname{COM}(2010)$, 7 July 2010, 344 final.

20 Regulation No 1219/2012 of the European Parliament and of the Council of 12 December 2012 establishing transitional arrangements for bilateral investment agreements between Member States and third countries OJ L 351/40 (2012).

21 Article 9 of Regulation No. 1219/2012.

22 See Preamble n. 5 of Regulation No. 1219/2012.

23 See Bungenberg (2013).

${ }^{24}$ See "Commission asks Member States to terminate their intra-EU bilateral investment treaties" Press Release (18 June 2015) IP/15/5198 available at $<$ http://europa.eu/rapid/press-release_ IP-15-5198_en.htm> accessed 9 February 2016.

25 According to Article $47 \mathrm{TEU}$, the EU has international personality. It can exercise the powers that the Member States have conferred on it (Article 5(1) TEU). In the fields of its competence, it may conclude international agreements which are binding on the institutions and its Member States (Articles 216(2) and 218 TFEU). See also Declaration no. 24 ('Declaration concerning the legal personality of the European Union') filed in the declarations annexed to the Final Act of the Intergovernmental Conference which adopted the Treaty of Lisbon. 
investment protection or in the form of BITs. ${ }^{26}$ In this respect, the EU is already party to one agreement with the possibility for investor-State dispute settlement (the Energy Charter Treaty $)^{27}$ and a number of other agreements are currently under negotiation or in the last stages of negotiations, like with Singapore, Canada, USA and China. ${ }^{28}$

\section{THE INVESTMENT DISPUTE SETTLEMENT MECHANISM AFTER THE LISBON TREATY - THE EU AS A NEW 'LITIGATOR' IN INVESTMENT ARBITRATION?}

It is evident that the EU, from now, may be involved in investment-related disputes. In its 2010 Communication, the Commission was favorable to the idea of including investor-State dispute settlement (ISDS) mechanisms in future EU investment agreements.

In order to ensure effective enforcement, investment agreements also feature investorto-state dispute settlement, which permits an investor to take a claim against a government directly to the binding international arbitration. Investor-state dispute settlements that form a key part of the inheritance that the Union receives from Member State BITs, are important as an investment involving the establishment of a long-term relationship with the host state cannot be easily diverted to another market in the event of a problem with the investment. Investor-state is such an established feature of investment agreements that its absence would discourage investors and make a host economy less attractive.

For these reasons, future EU agreements including investment protection should include investor-state dispute settlement. This raises challenges relating, in part, to the uniqueness of investor-state dispute settlement in international economic law and to the Union as it is not historically a significant actor in this field. Current structures are, to some extent, ill-adapted to the advent of the Union. One example is the Convention on the Settlement of Investment Disputes between States and Nationals of Other States (the ICSID Convention). It is open to signature and ratification by states members of the World Bank or party to the Statute of the International Court of Justice. The European Union qualifies under neither. ${ }^{29}$

In particular, the Commission has highlighted the need to design a new investment dispute settlement system. ${ }^{30}$ The commission has emphasized that it should be structured in such a way as to prevent investors from bringing multiple or frivolous claims; to make the

${ }^{26}$ Article 207 TFEU provides that "for the negotiation and conclusion of agreements in the fields of $[\ldots]$ foreign direct investment, the Council shall act unanimously where such agreements include provisions for which unanimity is required for the adoption of internal rules". For a comment, Reinisch (2014) 111.

27 The Energy Charter Treaty (1994) is a sector agreement with fifty-four members by 2009 (including the European Union and Euratom), aiming at creating a legal framework that will encourage the development of a secure international energy supply through liberalized trade and investment among member States. In particular, Part III of the Energy Charter Treaty entitled 'Investment Promotion and Protection' is itself an investment treaty, influenced by the various European and American BITs in its structure, content and drafting. For a comment, Salacuse (2010) 102.

28 See point 3 of this paper.

29 European Commission's Communication, Towards a comprehensive European international investment policy, $\operatorname{COM}(2010)$, 7 July 2010, 343 final, 9-10).

${ }^{30}$ European Commission, Investment Protection and Investor-to-State Dispute Settlement in EU Agreements. Fact Sheet (November 2013). 
arbitration system more transparent; to allow stakeholders, such as NGOs, to make submissions and to enhance consistency in arbitral case law, possibly introducing a binding code of conduct for arbitrators. ${ }^{31}$

The European Parliament (EP) has made it clear that there is a need "in order to include greater transparency, [for] the opportunity for parties to appeal, [for] the obligation to exhaust local judicial remedies where they are reliable enough to guarantee due process, [for] the possibility to use amicus curiae briefs and [for] the obligation to select one single place of investor-state arbitration". ${ }^{32}$ However, in 2013 the attitude of the EP has apparently changed and expressed the view that it is not a necessity to include ISDS provisions in future EU investment agreements: "[...T]heir inclusion should be a conscious and informed policy choice that requires political and economic justification. Even if there is a general policy choice in favour, the question whether to include ISDS should be decided for each International Investment Agreement in the light of the particular circumstances". ${ }^{33}$

It is also worth noting that the US, when negotiating its FTA with Australia, did not insist on including any direct investor-state dispute settlement mechanism because of "the fact that both countries have robust, developed legal systems for resolving disputes between foreign investors and government', ${ }^{34}$

It remains to be seen how much weight the Council and the Commission will give to this statement. However, the inclusion of ISDS provisions in the investment-related agreement negotiations with Singapore, Canada and the USA - to name the most important ones $-{ }^{35}$ does not seem to follow the EP's suggestion.

It follows that a foreign investor may be involved in investment arbitration not only against an EU Member State but also against the EU itself and it should be possible to have investor-EU arbitrations as well as investor-State arbitrations.

Nothing in the Treaties excludes that the EU may be subject, at least in principle, to binding international dispute settlements. The 1963 Association Agreement with Turkey provided that the Association Council might defer any dispute between the parties to the 'Court of Justice of the European Communities or to any other existing court or tribunal'. ${ }^{36}$

31 European Parliament, Committee on International Trade, Report on the Future European International Investment Policy, 2010/2203(INI), 22 March 2011, paragraph 31 and European Commission, Proposal for a Regulation of the European Parliament and the Council establishing a framework for managing financial responsibility linked to investor-State dispute settlement tribunals established by international agreements to which the European Union is party, $\operatorname{COM}(2012), 21$ June 2012, 335 final.

32 European Parliament, Committee on International Trade, Report on the Future European International Investment Policy, 2010/2203(INI), 22 March 2011, para. 31.

33 European Parliament, Amendment 3, Procedure 2012/0163(COD), P7_TA-PROV(2013)0219, 23 May 2013 available at <http://www.europarl.europa.eu>accessed 9 February 2016 while adopting an amendment to the text proposed by the Commission for a Regulation establishing a framework for managing financial responsibility linked to investor-state dispute settlement tribunals established by international agreements to which the European Union is party.

34 Australian Government Department of Foreign Affairs and Trade, Australia-United States Free Trade Agreement. Fact Sheets - Investment available at $<$ http://www.dfat.gov.au $>$ accessed 9 February 2016.

35 See in point 3 of this paper.

${ }^{36}$ Article 25, paragraph 2 of the EC-Turkey Association Agreement (1973). 
Also subsequent bilateral agreements with third countries came up with provisions on thirdparty arbitration. ${ }^{37}$

With respect to the agreement establishing the European Economic Area (EEA), the ECJ held that an international agreement providing for a system of courts that can take binding decisions on the institutions is in principle compatible with EU law. ${ }^{38}$ At the same time, the Court recalled that third-party arbitration cannot substitute the role of the Court in interpreting EU law. ${ }^{39}$ In the light of those directions, the relevant chapter in the EEA Agreement was revised. ${ }^{40}$ Under the new arbitration system laid down in Article 111(3) of the EEA Agreement, no question of interpretation of provisions of the agreement which are identical to provisions of EU law may be dealt with by the international arbitrators. Rather, the Contracting Parties to the dispute may agree to request the ECJ to give a ruling on the interpretation of the relevant rules. ${ }^{41}$ Since the Court did not consider the dispute settlement system as adversely affecting the autonomy of the EU legal order, it accepted that type of provision. ${ }^{42}$ Consequently, the EU can subject itself to various types of binding international dispute settlement mechanisms as long as the autonomy of EU law is not affected. ${ }^{43}$

It remains to be seen whether an investor-State arbitration involving the EU would be in conformity with the EU legal regime. This seems possible, albeit bearing in mind the caveat of the ECJ with respect to dispute settlement resolutions provided for by other international agreements, namely that the autonomy of the EU law is not affected. This means that no question of interpretation of provisions of the agreement which are identical to provisions of EU law may be dealt with by international arbitrators.

The EU is already a party to the Energy Charter Treaty (ECT), which includes an elaborate investor-State disputes settlement regime. It is apparent from the statement made

37 See Articles 184 and 185 of the EC-Chile Association Agreement (2002). For a comment, Hoffmeister (2012) 79.

38 ECJ, Opinion 1/91 Opinion delivered pursuant to the second subparagraph of Article 228 (1) of the Treaty - Draft agreement between the Community, on the one hand, and the countries of the European Free Trade Association, on the other, relating to the creation of the European Economic Area, ECR I-06079 (1991), para. 40.

39 ECJ, Opinion 1/91 Opinion delivered pursuant to the second subparagraph of Article 228 (1) of the Treaty - Draft agreement between the Community, on the one hand, and the countries of the European Free Trade Association, on the other, relating to the creation of the European Economic Area, ECR I-06079 (1991), paras. 41-46.

40 Agreement on the European Economic Area between the European Communities, their Member States and the Republic of Austria, the Republic of Finland, the Republic of Iceland, the Principality of Liechtenstein, the Kingdom of Norway, the Kingdom of Sweden and the Swiss Confederation (1994).

${ }^{41}$ Article 111(3) of the EEA Agreement.

42 ECJ, Opinion 1/92 Opinion pursuant to the second subparagraph of Article 228 (1) of the EEC Treaty - Draft agreement between the Community, on the one hand, and the countries of the European Free Trade Association, on the other, relating to the creation of the European Economic Area, ECR I-02821 (1992), fourth finding.

43 ECJ, Opinion 1/00 Opinion pursuant to Article 300(6) EC - Proposed agreement between the European Community and non-Member States on the establishment of a European Common Aviation Area, Opinion of the Court,ECR I-03493 (2002), paras.12-13. For a comment, see Hoffmeister (2012) 80. 
by the EU in relation to the ECT that the EU can become a party to an investment arbitration proceeding if that proceeding pertains to issues for which it bears the competence. ${ }^{44}$

Usually, investor-State arbitrations take place within the framework of the ICSID Convention. However, it does not seem possible to envisage an investor-EU ICSID arbitration. Indeed, the EU cannot become a party to the 1965 Convention for the Settlement of Investment Disputes between States and Nationals of Other States (ICSID Convention) as the Convention currently does not foresee accession by an international organization. Whether and how the ICSID Convention could be changed, in this respect, remains an open question. $^{45}$

Nevertheless, the European Commission is likely to intervene as amicus curiae $^{46}$ to protect EU interest in the proper interpretation and application of EU law in ICSID arbitration cases brought against EU Member States. ${ }^{47}$

There are currently several arbitral proceedings of foreign investors against EU Member States based on BITs between EU Member States and/or concerning substantive legal problems related to EU law in which the Commission has filed amicus curiae briefs. ${ }^{48}$ In the light of guaranteeing uniform interpretation of the Treaties it is worth recalling, that the Commission can bring infringement proceedings before the ECJ under Article 258 TFEU against Member States that refuse or fail to renegotiate their BITs in compliance with Article 351(2) TFEU.This has already happened against Austria, Sweden and Finland. ${ }^{49}$ The Commission has recently sought to intervene in the Iberdrola v. Guatemala case, an ICSID proceeding under the Spain-Guatemala BIT. ${ }^{50}$ In its application, the Commision claimed to have a 'systemic interest' in the interpretation given to investment treaties concluded by EU Member States. ${ }^{51}$ However, the ad hoc Annulment Committee rejected the request. ${ }^{52}$

44 European Communities (Statement sent by Council and Commission on 17 November 1997), Energy Charter Secretariat, Transparency Document Policies, Practices and Conditions of Contracting Parties Listed in Annex ID not Allowing an Investor to Resubmit the Same Dispute to International Arbitration at a Later Stage as Provided by Contracting Parties (in accordance with Article 26(3)(b) (ii) of the Energy Charter Treaty). However, the statement makes it clear that "[t]he Court of Justice of the European Communities, as the judicial institution of the Communities, is competent to examine any question relating to the application and interpretation of the constituent treaties and acts adopted thereunder, including international agreements concluded by the Communities, which under certain conditions may be invoked before the Court of Justice". See Tietje (2009).

45 For a general assessment of the topic see Burgstaller (2012) 207 and Hindelang (2012) 179.

46 As a "non-disputing party" under Rule 37, paragraph 2 of the ICSID Rules of Procedure.

47 See Hoffmeister (2012) 104.

48 Eastern Sugar being the best known example in this regard (Eastern Sugar B.V. (Netherlands) v. The Czech Republic, SCC Case 088/2004, UNCITRAL ad hoc Arbitration). For a comment see Tietje (2009).

49 Commission of the European Communities v. Austria, Case C-205/06, ECR I-01301 (2009);Commission of the European Communities v. Sweden, Case C-249/06, ECR I-01335 (2009) and Commission of the European Communities v. Finland,Case C-118/07, ECR I-10889 (2009). See Kleinheisterkamp (2014) 457.

50 Iberdrola Energía S.A. v. Republic of Guatemala, ICSID Case No. ARB/09/5. However, this first attempt to intervene was "ill-timed" and was not accepted by ICSID ad-hoc committee. See Peterson (2014a).

51 Iberdrola Energía S.A. v. Republic of Guatemala, ICSID Case No. ARB/09/5.

52 Iberdrola Energía S.A. v. Republic of Guatemala, ICSID Case No. ARB/09/5, Decision on Annulment, 13 January 2015, para. 25. 
Moreover, the Commission requested without success to intervene as a non-disputing party in the ICSID AES v. Hungary case $\mathrm{e}^{53}$ and successfully in the Electrabel v. Hungary case. ${ }^{54}$ It is also seeking to intervene in a series of international arbitrations involving the Czech Republic against investors in the photovoltaic (solar) power sector arbitrated under the UNCITRAL procedural rules. ${ }^{55}$

A peculiar amicus petition was filed in the Micula v. Romania case. ${ }^{56}$ The Commission submitted that the applicable Sweden-Romania BIT should be interpreted in light of EU law in particular in light of EU state aid regulation, otherwise the award would be unenforceable in the EU. After the award was issued, the Commission informed Romania, by letter dated 26 May 2014 of its decision to issue a suspension injunction obliging Romania to suspend any action, which may lead to the enforcement of the pending part of the award. ${ }^{57}$ For the first time, the role adopted by the Commission has evolved from its mere participation as amicus curiae to an active stance against the enforcement of an ICSID award.

Only time will tell whether the EU will maintain its increasingly active presence as a non-disputing party and the effect of these interventions in investor-state proceedings. ${ }^{58}$

It is finally worth highlighting that most BITs do not require investors to exhaust local remedies and allows them to bring directly a claim before an international arbitral tribunal. Investment treaties concluded by the EU on such a basis would allow foreign investors to seek damages directly before an international arbitral tribunal. ${ }^{59}$

In this respect, there would be a different treatment compared to EU investors. Indeed, the ECJ has clearly recognized that it is a general principle common to the legal systems of

53 AES Summit Generation Limited and AES-Tisza Erömü Kftv. Republic of Hungary, ICSID Case ARB/07/22. The arbitral tribunal ruled that the EU could, at least in principle, intervene in the arbitration; however it denied access to the parties' submissions. For a comment see Hoffmeister (2012) 92 .

54 Even though the arbitral tribunal dismissed the case, it affirmed that ECT should be interpreted, if possible, in harmony with EU law, in that welcoming the Commissions submissions as amicus curiae. See Electrabel S.A. v. Republic of Hungary, ICSID Case No. ARB/07/19, Decision on Jurisdiction, Applicable Law and Liability, 30 November 2012, paras. 1.18 and 4.130.

55 UNCITRAL Cases Antaris Solar GmbH and others v. Czech Repulic, Natland Investment Group and others v. Czech Republic, I.C.W. Europe Investments Ltd v. Czech Republic, Voltaic Network GmbH v. Czech Republic, Photovoltaik Knopf Betriebs-GmbH v. Czech Republic and WA Investments-Europa Nova Limited v. Czech Republic (all still pending). On 11 July 2014, The European Commission wrote to the arbitral tribunals hearing the six claims and briefly explained why it wished to submit a longer brief in the cases. The Commission has raised the possibility that the arbitration cases, pending further scrutiny, may touch upon questions of EU law and that former benefits and incentives accorded to solar investors could constitute state-aid that needed to be eliminated in order for the Czech Republic to remain in compliance with EU law. For a comment, see Peterson (2014b).

${ }^{56}$ Ioan Micula, Viorel Micula, S.C. European Food S.A, S.C. Starmill S.R.L. and S.C. Multipack S.R.L. v. Romania, ICSID Case No. ARB/05/20.

57 European Commission, State aid SA.38517(2014/C) (ex 2014/NN) - Romania Implementation of Arbitral award Micula v Romania of 11 December 2013, C(2014) 6848 final, 1 October 2014, para. 5 .

58 For a comment see, among others, González-Bueno and Lozanoon (2015) and Tietje (2015) 205-247.

59 See Kleinheisterkamp (2014) 460. 
the Member States that the injured party must show reasonable diligence in limiting the extent of the loss or damage, or risk having to bear the loss or damage himself. ${ }^{60}$

The rule is therefore that an EU investor is under an obligation to first attempt to obtain the annulment of the measures by the wrongdoing Member State or of the EU acts that affect its investment before being able to resort to international arbitration. ${ }^{61}$ Future investment agreements concluded by the EU would therefore introduce a different treatment between EU and non-EU investors.

\subsection{In particular: who should be sued and who should pay? The issue of financial responsibility between EU and Member States}

Having determined that an investment arbitration involving the EU as a possible 'litigator' is compatible with the EU legal regime, it has to be assessed whether the EU or the Member State should be the proper defendant in a case brought by a foreign investor.

Issues arise from the allocation of the financial responsibility connected to investment arbitration as well as from the problem of ius standi. It is thus necessary to consider how to manage the financial consequences of such disputes in the light of the new exclusive competence of the EU in this field.

The preliminary consideration is that the competence allocation in external relations between the EU and its Member States must be considered as res inter alios acta for third States. This is quite an important issue within the European framework and one may wonder whether it may relieve defendant Member States from the financial burden deriving from their liability when assessed. ${ }^{62}$ The Commission has made a proposal for a Regulation of the European Parliament and the Council establishing a framework for managing financial responsibility linked to investor-State dispute settlement tribunals established by international agreements to which the European Union is party on 21 June 2012 (Draft Regulation). ${ }^{63}$ The relevant Regulation (No. 912/2014) was finally adopted on 23 July $2014^{64}$ and entered into force on 17 September $2014 .^{65}$

The Commission has stressed in the Draft Regulation that the external responsibility of the EU must be determined 'on the basis of the competence for the subject matter of the international rules in question, as set down in the Treaty'. ${ }^{66}$ This was made clear in the

${ }^{60}$ ECJ, J.M. Mulder, W.H. Brinkhoff, J.M.M. Muskens, T. Twijnstra and Otto Heinemann v Council of the European Union and Commission of the European Communities, Joined Cases C-104/89 and C-37/90, ECR 1992 I-03061, para. 33.

${ }^{61}$ ECJ, Metallgesellschaft Ltd and Others (C-397/98), Hoechst AG and Hoechst (UK) Ltd (C410/98) v Commissioners of Inland Revenue and HM Attorney General, Joined cases C-397/98 and C-410/98, ECR I-01727 (2001), paras. 104-106. For a comment, Kleinheisterkamp (2014) 460.

62 See Tietje (2009).

63 Proposal for a Regulation of the European Parliament and of the Council establishing a framework for managing financial responsibility linked to investor-state dispute settlement tribunals established by international agreements to which the European Union is a party, OJ L 257.

${ }^{64}$ Published in the Official Journal of the European Union on 28 August 2014. For a very first detailed analysis of the Regulation, just before its adoption, see Cafari Panico (2014).

${ }_{65}$ Article 25 of Regulation No 912/2014. For a general analysis of the Regulation, see Dimopoulos (2014) 1671 and Baetens (2014) 1203.

${ }^{66}$ Explanatory Memorandum of the European Commission, Proposal for a Regulation of the European Parliament and of the Council establishing a framework for managing financial responsibility linked to investor-state dispute settlement tribunals established by international agreements to which the European Union is a party, $\operatorname{COM}(2012), 21$ June 2012, 335 final, 4. 
Regulation 912/2014, where Preamble n. 3 affirms that "[i]nternational responsibility for treatment subject to dispute settlement follows the division of competences between the Union and the Member States". As a consequence, the Union will in principle be responsible for defending any claims alleging a violation of rules included in an agreement which fall within the Union's exclusive competence, irrespective of whether the treatment at issue is afforded by the Union itself or by a Member State.

The Regulation is built upon three main principles: The overall operation of the allocation of financial responsibility must be 'budget neutral' as regards the EU, meaning that the EU should only bear the costs which are triggered by acts of its own institutions; a third-country investor should not be disadvantaged by the need to manage the financial responsibility within the EU and the mechanism must respect the fundamental principles governing the EU's external action as established by the Treaties and the case law of the ECJ, in particular that of unity of external representation and of sincere co-operation. ${ }^{67}$

Both the Draft Regulation and Regulation 912/2014 follow the general pattern provided in the 2011 ILC's Draft Articles on the Responsibility of International Organizations (DARIO) ${ }^{68}$ in determining the apportionment criteria of financial responsibility. Even though the latter document is not a binding act under international law, as it has rightly stated "[t]he implications of the Draft Articles are not to be underestimated. They will affect states operating through IOs, as well as IOs directly. [T] hey do set new baselines with regards to the consequences of wrongful actions, including the rules of attribution and the standard for reparations". ${ }^{9}$

Chapter IV, Part II (Articles 14-19) of the DARIO deals specifically with the responsibility of an international organization with regard to the actions of its Member States.

When an organization aids or assists the State in the wrongful act or where the organization directs, controls the State or exercises coercion, the organization bears responsibility for the actions of the Member State. Furthermore, where an international organization circumvents its international obligations by "adopting a decision binding member States [...] to commit an act that would be internationally wrongful if committed by the former organization", the organization maintains the responsibility for the wrongful act. ${ }^{70}$ Similarly, where an international organization authorises a Member State to commit an act that circumvents its international obligations, the organization bears responsibility accordingly. ${ }^{71}$ Nevertheless, State responsibility remains intact and the organization's

${ }^{67}$ Explanatory Memorandum of the European Commission, Proposal for a Regulation of the European Parliament and of the Council establishing a framework for managing financial responsibility linked to investor-state dispute settlement tribunals established by international agreements to which the European Union is a party, $\operatorname{COM(2012),~} 21$ June 2012, 335 final, 2. See Cafari Panico (2014) for one of the first analysis of the Regulation. The paper, even though published just before the adoption of the Regulation, offers a comprehensive overview of the structure of the Regulation and its main implications for future negotiations of investment agreements by the European Commission. This paper offers a more updated overview of the topic, in the light of the most recent outcomes of the recent negotiations with the USA, Canada and Singapore, together with a comparative analysis of the experience of the EU as a litigator before WTO dispute settlement bodies.

68 International Law Commission, Draft Articles on the Responsibility of International Organizations, with Commentaries, 2011. For a comment, Tietje (2012)

${ }^{69}$ See Boon (2011)

${ }^{70}$ Article 17 of the DARIO.

71 Article 17 of the DARIO. 
responsibility may be "secondary" or "concurrent".72 The result may be the "joint" responsibility of both the member state and the organization for the action in question. ${ }^{73}$

A special provision with respect to the EU has been adopted in Article 64 of the DARIO, which provides as follows: "these draft articles do not apply where and to the extent that the conditions for the existence of an internationally wrongful act or the content or implementation of the international responsibility of an international organization, or of a State in connection with the conduct of an international organization, are governed by special rules of international law. Such special rules of international law may be contained in the rules of the organization applicable to the relations between an international organization and its members." 74

The ILC's Commentary(4) to Article 64 recognized the existence of a special rule on attribution, to the effect that, in the case of a European Community act binding a member State, State authorities would be considered as acting as organs of the Community.

In this respect, one has to rely on Regulation 912/2014, which provides for the criteria to determine the financial responsibility between the EU and the Member State and the ius standi before investor-State/EU dispute settlement tribunals.

Article 3 of the Regulation 912/2014 links financial responsibility to the question of who, the EU or a Member State, actually undertakes the conduct giving rise to the foreign investor's claim. ${ }^{75}$ This means that where the measures concerned are taken by the EU institutions, then financial responsibility should rest with the EU institutions ${ }^{76}$. On the other hand, then financial responsibility should rest with that Member State where the complained measures are taken by a Member State of the EU. ${ }^{77}$

It is only where the actions of the Member State are "required" by the law of the EU that financial responsibility should lie with the $\mathrm{EU}^{78}$. The situation is one of a member State transposing an EU legislative act into its domestic regime.

After having determined the criteria for apportionment of financial responsibility, Chapter III of the Regulation provides for the criteria to determine who should act as a respondent in an arbitral dispute (ius standi). Similar to financial responsibility, where the EU has afforded the treatment, the EU will act as the respondent in the claim ${ }^{79}$. Likewise, the Member State acts as the respondent where it has afforded the treatment. ${ }^{80}$ However, the EU may act as a respondent, when the EU may bear "all or at least part of the potential financial responsibility" and "the dispute also concerns treatment afforded by the institutions, bodies, offices or agencies of the Union" 81

72 See Stumer (2007) 555.

73 See Tietje (2012) and Hoffmeister (2010) 727.

74 See Hoffmeister (2010) 729.

75 See Kleinheisterkamp (2014) 458.

76 Article 3, paragraph 1, letter a of the Regulation.

77 Article 3, paragraph 1, letter b of the Regulation. It seems that the criteria for apportionment of financial responsibility follow those envisaged in CETA.

78 Article 3, paragraph 1, letter $\mathrm{c}$ of the Regulation.

79 Article 4 of the Regulation.

80 According to Article 5 of the Regulation. Article 9, paragraph 1, letter b leaves the possibility that a member State may turn down responsibility by not reacting within 45 days after receiving the notice of initiation of the arbitral proceedings.

${ }^{81}$ Article 9, paragraph 2 of the Regulation. See Tietje (2012) 
The Commission has proposed two other exceptions in the Draft Regulation, namely that similar claims might be brought and that the dispute was based on unsettled issues of law that may arise again. ${ }^{82}$ The final version of the Regulation 912/2014 does not include those last two exceptions and instead has added a new kind of exception, namely that the Union is to act as the respondent where similar treatment is being challenged in a related claim against the Union in the WTO, where a panel has been established and the claim concerns the same specific legal issue, and where it is necessary to ensure a consistent argumentation in the WTO case. ${ }^{83}$

However, it is not very clear which practical advantage this conduct may have given the absence of the rule of precedent in investment arbitration and that investment arbitrators are certainly not bound by WTO decisions. ${ }^{84}$

Interestingly, the Regulation in question does not provide for the possibility of joint responsibility of the EU and its Member States and differs from the general rules set out in DARIO and the rules of EU as a respondent before WTO dispute settlement organs. ${ }^{85}$ The regulation adopts a "either/or" approach in the determination of the respondent status and the allocation of financial responsibility.

Moreover, the Regulation provides no explanation for how the parties should proceed if a difference arises between the Member State and the Commission about the determination of who should be the respondent. An answer may be found in the TFEU as a decision by the Commission can be reviewed by the ECJ in accordance with Article 263(1) TFEU and the Member State has the opportunity to raise a claim against the Commission under Article 263(2) TFEU. However, such proceedings are time-consuming and it could be a disadvantage for the foreign investor. ${ }^{86}$

Where the EU acts as a respondent but the Commission determines that the Member State must pay, whether fully or partially, the Commission, after consultations with the Member State, can adopt a decision stating the amount due by the Member State. ${ }^{87}$ This allows the EU to be reimbursed for the awards paid. ${ }^{88}$ Where the Member State objects to the decision by the Commission, the Commission can adopt another decision that similarly requires that the member State pay. A decision could also be adopted that requires the member State to make financial contributions prior to the proceedings rather than waiting until after the award has been paid by the Commission. ${ }^{89}$ These payments would be considered as internal assigned revenue and thus not impacting the EU budget. Where the tribunal determines that the investor is liable for the costs, the MS would be reimbursed. ${ }^{90}$

The Regulation still leaves some core legal problems unresolved. In particular, one should distinguish two particular situations that may arise. The first is when Member States(s) or the EU breaches EU law, thus causing damages to foreign investors and the other is when the acts of the Member State(s) or the EU are lawful under EU law but nonetheless cause damages to foreign investors.

82 Article 8, paragraph 2, letters c and d of the Draft Regulation.

83 Article 9, paragraph 3 of the Regulation.

84 See, e.g., RigoSureda (2009) 830.

85 See point 2.2 of this paper.

86 See Tietje (2012)

${ }^{87}$ For a comment, see Tietje (2012)

88 Article 19 of the Regulation

89 Article 20 of the Regulation.

90 Article 20, paragraph 2 of the Regulation. 
Whereas the liability of Member States or of the Union for legislative acts that violate EU law is clearly recognized by the ECJ, ${ }^{11}$ the situation is different regarding the Member State(s) or EU's liability for acts that are legal under EU law. In this respect, Article 340(2) TFEU provides that "[i]n the case of non-contractual liability, the Union shall, in accordance with the general principles common to the laws of the Member States, make good any damage caused by its institutions or by its servants in the performance of their duties".

The question of 'objective liability' has already arisen in the FIAMM and Fedon cases where European companies sued the EU for losses suffered as a consequence of retaliation measures that the US imposed on the EU following the decision of a WTO panel. The ECJ addressed the question of whether the Union could be considered liable for legislative acts that cause loss to an investor but which are in full conformity with the Treaties. ${ }^{92}$ The Grand Chamber of the ECJ affirmed that a comparative analysis of the laws of the Member States did not allow assessing 'the possible existence of a principle of liability in the case of a lawful act or omission of the public authorities, in particular where it is of a legislative nature' ${ }^{93}$ The ECJ concluded that as Community law currently stands, no liability regime exists under which the Community can incur liability for conduct falling within the sphere of its legislative competence in a situation where any failure of such conduct to comply with the WTO agreements cannot be relied upon before the Community courts. ${ }^{94}$

The problem remains also with future investment agreements where the EU would expose itself to financial responsibility for its legislative acts that are perfectly legal under EU law but which could be considered by some arbitral tribunal to be in breach of standards of an investment treaty. ${ }^{95}$ One should have expected such a legal problem to have been addressed by a regulation specifically aimed at dealing with financial responsibility "linked to investor-to-state dispute settlement tribunals".

Furthermore, one might discuss whether the internal distribution of financial responsibility as resulted from the Regulation is convincing and in line with Article 207(6) TFEU, which expressly provides that the competences of the EU in the field of the common commercial policy shall not affect the delimitation of competences between the Union and the Member States, and shall not lead to harmonization of legislative or regulatory provisions of the Member States in so far as the Treaties exclude such harmonization.

Indeed, it is likely that the international responsibility of the EU with regard to an investment agreement touches upon internal competence of the Member State. ${ }^{96}$

91 ECJ, Fabbrica italiana accumulatori motocarri Montecchio SpA (FIAMM) and Fabbrica italiana accumulatori motocarri Montecchio Technologies LLC (C-120/06 P), Giorgio Fedon \& FigliSpA and Fedon America, Inc. (C-121/06 P) v Council of the European Union and Commission of the European Communities, Joined cases C-120/06 P and C-121/06 P,ECR I-06513 (2008), paras.170 and 175 .

92 See Kleinheisterkamp (2014) 461.

93 See ECJ, Fabbrica italiana accumulatori motocarri Montecchio SpA (FIAMM) and Fabbrica italiana accumulatori motocarri Montecchio Technologies LLC (C-120/06 P), Giorgio Fedon \& Figli SpA and Fedon America, Inc. (C-121/06 P) v Council of the European Union and Commission of the European Communities, Joined cases C-120/06 P and C-121/06 P,ECR I-06513 (2008), para. 175.

${ }^{94}$ ECJ, Fabbrica italiana accumulatori motocarri Montecchio SpA (FIAMM) and Fabbrica italiana accumulatori motocarri Montecchio Technologies LLC (C-120/06 P), Giorgio Fedon\& Figli SpA and Fedon America, Inc. (C-121/06 P) v Council of the European Union and Commission of the European Communities, Joined cases C-120/06 P and C-121/06 P,ECR I-06513 (2008), para. 176.

95 See Kleinheisterkamp (2014) 463.

96 See Tietje (2012). 
Thus, for example, even though the EU may conclude an international investment agreement that applies also to investment in the area of education, ${ }^{97}$ the organization of domestic education remains a regulatory competence of Member States. ${ }^{98}$ In the event of a claim brought by a foreign investor in the education sector against certain legislative measure adopted the Member State, either the Member State or the Commission could act as the respondent. Moreover, if the arbitral tribunal rules that the investment agreement has been violated, it has also the authority to rule on both financial compensation as well as on the conformity of the Member State's law on education with the relevant investment treaty. ${ }^{99}$

Therefore, an investment agreement concluded by the EU may also affect the internal competence of Member States. ${ }^{100}$

\subsection{The EU as a litigator before the WTO dispute settlement bodies: some useful lessons for the international investment arbitration system?}

The EU is an active litigator before WTO dispute settlement bodies. ${ }^{101}$ Even though the EU has never been involved in investment-related matters under WTO Agreements, it can be nonetheless useful to consider the attitude of the EU in the framework of the WTO dispute settlement mechanism in order to distill some useful guidelines for the international investment arbitration system.

Generally, scholars speak of a "[p]ositive experience of the practice in WTO dispute settlement", ${ }^{102}$ even if there appears to be little direct involvement of member States in WTO disputes. ${ }^{103}$ Although some States, particularly the United States of America, have tried to sue member States and the EU separately, no single EU member State has defended itself on its own and the EU has always acted as respondent in WTO cases, whether on its own or together with member States.

97 This may be subject to the requirement of unanimity decision in the Council according to Article 207, paragraph 4 TFEU. The example is from Tietje (2012).

98 Article 165, paragraph 4 TFEU: "In order to contribute to the achievement of the objectives referred to in this Article: the European Parliament and the Council, acting in accordance with the ordinary legislative procedure, after consulting the Economic and Social Committee and the Committee of the Regions, shall adopt incentive measures, excluding any harmonisation of the laws and regulations of the Member States". See also Article 6 TFEU: "The Union shall have competence to carry out actions to support, coordinate or supplement the actions of the member States. The areas of such action shall, at European level, be: [...] (e) education, vocational training, youth and sport [...]" and Article 2, paragraph 5 TFEU: "In certain areas and under the conditions laid down in the Treaties, the Union shall have competence to carry out actions to support, coordinate or supplement the actions of the Member States, without thereby superseding their competence in these areas".

99 See Tietje (2012).

100 Tietje (2012).

101 The EU has been a WTO member - together with its member States - since 1 January 1995. The 28 member States of the EU are also WTO members in their own right. See information about the EU membership in WTO at the official WTO's website: https:/www.wto.org/english/thewto_e/ countries e/european communities e.htm.

102 See Danieli and Hahn (2013) 58, Kuijper (2010) 224 (speaking of "intense cooperation" in the context of "the 'Airbus/Boeing' litigation") and Rosas (2003) 299 ("the handling of WTO disputes $[\ldots]$ has proceeded on a pragmatic basis, with a central role for the Commission, and can by and large be counted among the EU success stories").

103 Baetens (2014) 1228. 
WTO panels have generally adopted a conduct-based approach, according to which the responsibility "follows" the conduct. Thus, the EU should be responsible for the conduct of its own organs, while member States should be responsible for their own conducts. ${ }^{104}$ More specifically, WTO panels have been receptive to the idea that Member States' organs can act asde facto organs of the EU. ${ }^{105}$ Consequently, WTO panels have shown a large amount of pragmatism on the issue of attributing member States' conduct to the EU whilst at the same time they did not exclude the possibility of joint responsibility. ${ }^{106}$

The EC - Trademarks and Geographical Indications case is worth mentioning in this respect as the panel accepted the EU's submission that Community laws are generally not executed through authorities at Community level but rather through recourse to the authorities of its Member States which, in such a situation, 'act de facto as organs of the Community, for which the Community would be responsible under WTO law and international law in general'. ${ }^{107}$

There is a major difference, however, between trade and investment law as described in the WTO Dispute Settlement Understanding: "The aim of the dispute settlement mechanism is to secure a positive solution to a dispute. [...] In the absence of a mutually agreed solution, the first objective of the dispute settlement mechanism is usually to secure the withdrawal of the measures concerned if these are found to be inconsistent with the provisions of any of the covered agreements. The provision of compensation should be resorted to only if the immediate withdrawal of the measure is impracticable and as a temporary measure pending the withdrawal of the measure, which is inconsistent with a covered agreement". ${ }^{108}$

In contrast, the goal of investment arbitration is first and foremost to secure compensation for the individual investor when the host state violates the terms of an international investment agreement (IIA). The financial implications are significant, which motivated the Commission in proposing the Draft Regulation and the Commission may be eager to act as respondent. However, the Commission may also be equally eager to recover, at least part of, the award from the Member State, where the treatment in question was, at least partly, accorded by the Member State. ${ }^{109}$

In summary, it appears difficult to distil a general rule for the allocation of financial responsibility between the EU and its member States from the existing WTO case-law which can be also useful for the investment arbitration system. Consequently, it remains to be seen to what extent the WTO's pragmatism could be translated into the different system of investment arbitration. ${ }^{110}$

104 Baetens (2014) 1236.

105 See Dimopoulos (2011) 261.

106 Dimopoulos (2011) 1241.

107 Panel Report, European Communities-Protection of Trademarks and Geographical Indications for Agricultural Products and Foodstuffs, WT/DS174/R, 15 March 2005, para. 7.98.

108 Article 3, para 7 of the Understanding on Rules and Procedures Governing the Settlement of Disputes, Marrakesh Agreement Establishing the World Trade Organization, Annex 2, 1869 U.N.T.S. 401, 15 April 1994.

109 Baetens (2014) 1244.

110 Baetens (2014) 1244. 


\section{THE ON-GOING NEGOTIATIONS BETWEEN EU AND THIRD COUNTRIES FOR THE CONCLUSION OF INVESTMENT-RELATED AGREEMENTS}

As previously mentioned, the EU is currently negotiating and/or concluding investmentrelated international agreements with third countries. The agreements, which are being concluded, with Singapore, Canada, USA and China are of particular interest as they include, or likely to include, specific provisions on FDI protection and on the investor-State dispute settlement mechanism. ${ }^{111}$

EU and Singapore completed the negotiations for a comprehensive free trade agreement (FTA) on 17 October 2014. ${ }^{112}$ In July 2015 the Commission deposited a request for an Advisory Opinion from the ECJ on the competence to sign and ratify the FTA with Singapore and the Commission submitted the following questions to the ECJ: "Does the Union have the requisite competence to sign and conclude alone the Free Trade Agreement with Singapore? More specifically, which provisions of the agreement fall within the Union's exclusive competence? Which provisions of the agreement fall within the Union's shared competence? Is there any provision of the agreement that falls within the exclusive competence of the Member States?"113

The Opinion will be restricted to the competence to conclude the EU-Singapore FTA but it will determine the overall division of horizontal and vertical competences in relation to other FTAs currently being negotiated, like the Transatlantic Trade and Investment Partnership (TTIP) with the USA, or concluded but not yet in force, the Comprehensive Trade and Economic Agreement (CETA) with Canada. In this respect, the forthcoming Opinion 2/15 has the potential of becoming a fundamental Opinion of the Court that would set the debate on the upcoming years on the issue of the division of competences in the field of trade and investment protection. ${ }^{114}$

The FTA with Singapore provides transparency rules, ${ }^{115}$ binding interpretations to be given by the EU and Singapore, ${ }^{116}$ a code of conduct for arbitrators, ${ }^{117}$ the provision of

111 For a comprehensive and updated overview of current negotiations, see the document prepared by the European Commission, Overview of FTA and other Trade Negotiations. Updated December 2015 available at $<$ http://trade.ec.europa.eu/doclib/docs/2006/december/tradoc_118238. pdf $>$ accessed 9 February 2016. For a general overview, see Bronckers (2015) 1-24.

112 The text of the draft agreement is available on DG Trade's website including the draft investment protection chapter of the agreement. The text needs now to be formally approved by the European Commission and then agreed upon by the Council of Ministers and ratified by the European Parliament. All information available at the official website <http:/ec.europa.eu/trade/policy/ countries-and-regions/countries/singapore> accessed 9 February 2016.

113 The application initiating proceedings has been lodged by the Commission on 10 July 2015. See Request for an Opinion submitted by the European Commission pursuant to Article 218(11) TFEU, Opinion 2/15, 10 July 2015.

114 Delgado Casteleiro (2015).

115 See Article 9.22 and Annex 9-G (Rules On Public Access To Documents, Hearings And The Possibility Of Third Persons To Make Submissions) of the EU-Singapore FTA, Authentic text as of May 2015, available at $<$ http://trade.ec.europa.eu/doclib/press/index.cfm?id=961 $>$ accessed 9 February 2016.

116 See Article 9.19 (Applicable Law and Rules of Interpretation) of the EU-Singapore FTA.

117 See Annex 9-F (Code Of Conduct For Arbitrators And Mediators) of the EU-Singapore FTA. 
early dismissal for unfounded claims ${ }^{118}$ and the "loser-pays" principle regarding the investor-State dispute settlement mechanism. ${ }^{119}$

The EU-Singapore FTA in its Article 9.15, provides the following for the ius standi in investor-State dispute settlement mechanisms:

"1. [...] The notice of intent to arbitrate shall be sent [by the foreign investor] to the Union $[\ldots]$.

2. [...T]he Union shall make a determination of the respondent within two months from the date of receipt of the notice. The Union shall inform the claimant of this determination immediately [...].

3. Where no determination of the respondent has been made pursuant to paragraph 2 , the following shall apply:

(a) in the event that the notice of intent to arbitrate exclusively identifies treatment by a Member State of the Union, that Member State shall act as respondent;

(b) in the event that the notice of intent to arbitrate identifies any treatment by an institution, body or agency of the Union, the Union shall act as respondent.[...]"

It follows that, in case of a notice of intent to arbitrate from a Singaporean investor, the EU shall inform the investor whether the EU or the relevant Member State will act as the respondent in the case at hand. However, if such a determination is not possible, or the EU is unwilling to be the respondent, the identification of the respondent should be made according to the notice of intent to arbitrate made by the investor. The investor has the, albeit residual, possibility to "choose" the respondent in the case at hand. This is contrast to the scope of the $912 / 2014$ Regulation, which does not leave the possibility for the "choice" of the appropriate respondent to sue before an arbitral tribunal.

The EU concluded negotiations with Canada for a Comprehensive Trade and Economic Agreement (CETA) in August 2014. ${ }^{120}$

The regulation of the investor-State dispute settlement mechanism resembles the FTA with Singapore when it provides for transparency rules, ${ }^{121}$ binding interpretations to be given by the EU and Canada, ${ }^{122}$ a code of conduct for arbitrators, the provision of early dismissal for unfounded claims ${ }^{123}$ and the "loser-pays" principle. ${ }^{124}$

The procedure for the determination of the respondent in case of disputes with the EU and/or one of its Member States is similar to the Singapore FTA Protocol. Accordingly, the EU shall inform the investor of whether the EU or the relevant Member State will act as the respondent in the case at hand. If such a determination fails, the identification of the

118 See Article 9.20 (Claims Manifestly Without Legal Merit) of the EU-Singapore FTA.

119 See Article 9.26 (Costs) of the EU-Singapore FTA. For a general outline, see European Commission, Investment Provisions in the EU-Singapore Free Trade Agreement. Fact Sheet (17 October 2014) available at <http://trade.ec.europa.eu/doclib/docs/2014/october/tradoc_152845.pdf> accessed 9 February 2016.

120 The text of the CETA agreement has been made public on the EU website $<$ http://trade.ec. europa.eu/doclib/docs/2014/september/tradoc_152806.pdf $>$ accessed 9 February 2016. The text will be subject to legal revision in order to verify the internal consistency and to ensure that the formulations of the negotiating results are legally sound. It will thereafter be transmitted to the Council of the European Union and to the European Parliament for ratification.

121 Article 8.36 of the Draft Text of CETA.

122 See Article 8.31 of the Draft Text of CETA.

123 See Article 8.32 of the Draft Text of CETA.

124 See Article 8.39 of the Draft Text of CETA. 
respondent should be made according to the notice of intent to arbitrate made by the investor. $^{125}$

Another Free Trade Agreement which should soon be concluded by the EU is the TTIP Agreement with the USA. The negotiations, which started in July 2013, are still on-going. There was a public consultation on investment in TTIP between March and July 2014 organized by the Commission in order to collect views from the relevant stakeholders with a final report issued by the Commission in January 2015. The Commission issued on 5 May 2015 a Concept Paper on TTIP and beyond based upon these consultations and on 16 September 2015 it released an internal document Draft Text on TTIP focusing on investment protection. The Commission will consult with member States, the Council and the European Parliament before presenting formal text proposal to USA. ${ }^{126}$

The proposal of a new Investment Court System for TTIP in the most recent version of the Draft Text of the TTIP elaborated by the Commission issued on 16 September 2015 is worth mentioning as it builds on the substantial input received from the European Parliament, Member States, national parliaments and stakeholders. ${ }^{127}$ The Investment Court System will be composed of a first instance Tribunal and an Appeal Tribunal. ${ }^{128}$

The Draft Text of the TTIP differs from the above-mentioned FTAs concluded with Singapore and Canada regarding the determination of the respondent in case of disputes with the EU and/or one of its Member States. According to Article 5 of the Draft Text of the TTIP, Request for determination of the respondent, the EU shall inform the investor whether the EU or the relevant Member State will act as the respondent in the case at hand but the provision does not provide for any kind of solution when such a determination fails. ${ }^{129}$

125 Article 8.21 of the Draft Text of CETA. For a critical analysis see Bungenberg (2013) and Deblock and Rioux(2010/11) 39-56.

126 For more detail information on the negotiation history of TTIP, see the official website of the Commission $<\mathrm{http}$ //ec.europa.eu/trade/policy/in-focus/ttip/index_en.htm> accessed 9 February 2016. For the most recent version of the Draft Text of TTIP, see the official Commission's website $<$ http:// trade.ec.europa.eu/doclib/docs/2015/september/tradoc_153807.pdf $>$ accessed 9 February 2016.

127 "Today, we're delivering on our promise - to propose a new, modernised system of investment courts, subject to democratic principles and public scrutiny", said Trade Commissioner Cecilia Malmström. "What has clearly come out of the debate is that the old, traditional form of dispute resolution suffers from a fundamental lack of trust. However, EU investors are the most frequent users of the existing model, which individual EU countries have developed over time. This means that Europe must take the responsibility to reform and modernise it. We must take the global lead on the path to reform". She added: "We want to establish a new system built around the elements that make citizens trust domestic or international courts. I'm making this proposal public at the same time that I send it to the European Parliament and the Member States. It's very important to have an open and transparent exchange of views on this widely debated issue". Quotation from the official Commission website available at $<\mathrm{http} / /$ trade.ec.europa.eu/doclib/press/index.cfm?id=1364> accessed 9 February 2016.

128 See more in detail Chapter II - Section 3 (Resolution of Investment Disputes and Investment Court System) of the Draft Text of TTIP.

129 Article 5 (Request for determination of the respondent) of the Draft Text of the TTIP: "1. [...When] the request concerns an alleged breach of the agreement by the European Union or a Member State of the European Union [...] the claimant shall deliver a notice to the European Union requesting a determination of the respondent.2. The notice shall identify the treatment in respect of which the claimant intends to initiate proceedings. Where treatment of a Member State of the European Union is identified, such notice shall also be sent to the Member State concerned.3. 
It remains to be seen what the final version of the text will look like and it is hoped that the drafting parties will add something in this respect.

The final investment agreement worth mentioning is the on-going negotiating text of a BIT between China and the EU. The decision to negotiate a EU-China BIT was announced at the $14^{\text {th }}$ China-EU Summit in February 2012, with the first round of negotiations taking place in January 2014. ${ }^{130}$ Since then, three negotiations round were held in 2014. If successful, it will be the first standalone EU BIT. The European Parliament required that the agreement should include “(...) effective state-to-state and investor-to-state dispute settlement mechanisms in order, on the one hand, to prevent frivolous claims from leading to unjustified arbitration, and, on the other, to ensure that all investors have access to a fair trial, followed by enforcement of all arbitration awards without delay". ${ }^{131}$

Although there are currently BIT arrangements between China and 27 EU Member States, ${ }^{132}$ the China-EU BIT negotiations would go much further than simply consolidating 'the existing BITs between China and 27 EU Member States into a single and coherent text'. ${ }^{133}$ The most challenging and promising issues are likely to be market access and dispute resolution. It remains to be seen how the forthcoming BIT will include the above mentioned solutions regarding in particular ius standi in investor-EU/Member State(s) dispute settlement mechanism.

\section{FRAMING A CONVINCING INVESTOR-EU/MEMBER STATE(S) INVESTMENT ARBITRATION MECHANISM. CONCLUDING REMARKS}

At first glance, the issues dealt with by the financial responsibility Regulation 912/2014 are mostly technical. However, by including rules on the conduct of investor-state dispute settlement procedures, the proposal anticipates and indirectly frames the rights that the future EU investment agreements can grant to non-EU investors. As a general rule, foreign investors will have to accept that they cannot choose against whom to bring their claims. ${ }^{134}$

However, the Regulation is neither sufficient nor always appropriate to guarantee legal certainty as to the involvement of the EU in future investor-EU/Member State(s) arbitrations. The paper has highlighted how the involvement of the EU in investment arbitration raises

The European Union shall, after having made a determination, inform the claimant within 60 days of the receipt of the notice referred to in paragraph 1 as to whether the European Union or a Member State of the European Union shall be the respondent. [...] 7. Nothing in this Agreement or the applicable arbitration rules shall prevent the exchange of all information relating to a dispute between the European Union and the Member State concerned."

130 The existing 1985 China-EC Trade and Economic Cooperation Agreement called for, among others, the elimination of technical barriers to trade and investment.

131 European Parliament Resolution of 9 October 2013 on the EU-China negotiations for a bilateral investment agreement(2013/2674(RSP)), para. 42.

132 For the complete list of BITs concluded by China see the UNCTAD website <http:// investmentpolicyhub.unctad.org/IIA/CountryBits> accessed 9 February 2016.

133 European Commission, Commission proposes to open negotiations for an investment agreement with China (23 May 2013) available at $<$ http://europa.eu/rapid/press-release_IP-13-458 en.htm> accessed 9 February 2016.

134 See Kleinheisterkamp (2014) 459. However, as it has been shown, the FTAs negotiated by the EU with Singapore and Canada, respectively, envisage the residual possibility that the respondent status can be determined according to the notice of intent to arbitrate made by the investor. See point 3 of this paper. 
concerns about compatibility with EU law. In this respect, the application of the Regulation seems to challenge the smooth functioning of investor-State arbitration proceedings. ${ }^{135}$

Bearing in mind that the investor bringing the claim should not be adversely affected by any disagreement between the EU and its Member States on the issue of allocation of financial responsibility, ${ }^{136}$ it should be ensured that future EU agreements provide a maximum of legal certainty for both investors and EU Member States in the matter.

It has been shown that EU negotiating practice indicate that an investor-State dispute settlement mechanism will be included in most international agreements that will be most likely to be concluded by the EU and its Member States jointly as mixed agreements. Member States are expected to conclude CETA and TTIP agreements together with the EU. ${ }^{137}$ However, the conclusion of mixed agreements does not make the determination of the role of the EU in investor-State arbitration any easier. On the contrary, unless investment arbitration provisions are carefully drafted, the determination of respondent status in accordance with the provisions of the Regulation can significantly affect legal certainty. This has happened with regard to the Singapore-EU FTA. Indeed, the Investment Chapter (as appears in the Draft Version of EU-Singapore FTA of October 2014, currently under legal revision) includes an ISDS mechanism. ${ }^{138}$ However, it makes no reference to the Regulation when considering who should act as the respondent in the investment arbitration against the EU/Member State(s), in that enhancing the confusion regarding the right application of the Regulation itself. ${ }^{139}$

This is particularly true for the most recent version of Draft Text of the TTIP, which does not envisage any kind of solution in case the EU is not able or willing to determine whether the EU or the Member State should act as a respondent in the case at hand.

Instead, both the FTA between EU and Singapore and the CETA with Canada provide for the, albeit residual, possibility that the respondent status can be determined according to the notice of intent to arbitrate made by the investor. ${ }^{140}$ In any case, none of the above mentioned international agreements include specific provisions for the allocation of financial responsibility between the EU and its Member States. Accordingly, only the provisions of the EU Regulation will apply to determine who should "pay" in case of investor-EU/Member State(s) arbitration.

Given the lack of a EU investment policy dealing with substantial treatment of both EU and non-EU investors, it would be much safer to pause the on-going negotiations with the important trading partners as Canada, the US and China and work on the substantial framework for FDI protection. It would be thus possible to ensure the highest possible degree of legal certainty towards EU and non-EU investors. It is worth noting that the term

135 Dimopoulos (2014) 1673-1674.

136 See European Commission Proposal for a Regulation of the European Parliament and of the Council establishing a framework for managing financial responsibility linked to investor-state dispute settlement tribunals established by international agreements to which the European Union is a party, 21 June 2012, COM(2012) 335 final, 2.

137 Commission Press Release, Speech: The Transatlantic Trade and Investment Partnership: The Real Debate (22 May 2014) available at <europa.eu/rapid/press-release_SPEECH-14-406_en. htm $>$ accessed 9 February 2016.

138 See articles 9.18-9.19 of the Draft available at <http://trade.ec.europa.eu/doclib/docs/2014/ october/tradoc_152844.pdf $>$ accessed 9 February 2016

139 For a general comment on the difficulties in applying the Regulation in future EU investmentrelated agreements, Dimopoulos (2014), 1687

140 See point 3 of this paper. 
"foreign direct investment" is mentioned only three times in the TFEU. ${ }^{141}$ The Treaties do not give any more indications on what the FDI protection in EU should look like. Maybe, given the importance of the issue, one should have expected a more articulated regulation in the Treaties.

An albeit weak effort can be found in the final version of the Regulation on financial responsibility. According to its preamble 4, "Union agreements should afford foreign investors the same high level of protection as Union law and the general principles common to the laws of the Member States grant to investors from within the Union, but not a higher level of protection. Union agreements should ensure that the Union's legislative powers and right to regulate are respected and safeguarded".

This would avoid discrimination between foreign and EU investor, making the framework for managing financial responsibility subject to the interpretative safeguard that future EU investment agreements cannot provide more protection to foreign investors than EU investors are granted under current EU law. This is certainly a politically attractive solution. However, it is not clear how the on-going negotiations will address these legal problems.

With the conclusion of the new international investment-related agreements by the EU with third countries, and the subsequent flow of arbitrations, it will be intriguing to see how the system developed by the Regulation effectively works in practice. ${ }^{142}$

\section{LITERATURE}

Baetens, F., Kreijen, G. and Varga, A., 'Determining International Responsibility Under the New Extra-EU Investment Agreements: What Foreign Investors in the EU Should Know' (2014) 47 Vanderbilt Journal of Transnational Law 1203-1260.

Boon, K., 'ILC Adopts Articles on the Responsibility of International Organizations', Opinio Juris Blog (13 June 2011) <http://opiniojuris.org/2011/06/13/ilc-adopts-articles-on-the-responsibilityof-international-organizations/>

Bronckers, M., 'Is Investor-State Dispute Settlement (ISDS) Superior to Litigation Before Domestic Courts? An EU View on Bilateral Trade Agreements' (2015) 18 Journal of International Economic Law 1-24.

Bungenberg, M., Griebel, J. and Hindelang, S. (eds), European Yearbook of International Economic Law 2011, Special Issue: International Investment Law and EU Law (Springer 2011).

Bungenberg, M. (ed.), EU and Investment Agreements. Open Questions and Remaining Challenges (Nomos 2013).

Bungenberg, M. and Herrmann, C. (eds), Common Commercial Policy after Lisbon (Springer 2013).

Burgstaller, M., 'Investor-State Arbitration in EU International Investment Agreements with Third States' (2012) 39 Legal Issues of Economic Integration 207-221.

Cafari Panico, R., 'Recent Developments in EU Investment Agreements',NYU Law Blog Transnational Notes (14 July 2014) <http://blogs.law.nyu.edu/transnational/2014/07/recentdevelopments-in-eu-investment-agreements>

Calamita, J.N., 'The Making of Europe's International Investment Policy: Uncertain First Steps' (2012) 39 Legal Issues of Economic Integration 301-330.

Danieli, L. and Hahn, M., 'You'll Never Walk Alone: The European Union and Its Member States in the WTO' (2013) European Yearbook of International Economic Law. Common Commercial Policy After Lisbon 49-63.

Deblock, C. and Rioux, M., 'From Economic Dialogue to CETA. Canada's Trade Relations with the European Union' (2010/11) 66 Canadian International Council: International Journal 39-56.

141 In articles 206 and 207 dealing with the EU common commercial policy.

142 Baetens (2014) 1260. 
Delgado Casteleiro, A., 'Four Cases for 2015 (IV) - Opinion 1/15 Concerning the Scope of the New Exclusive Competence on Foreign Direct Investment',DELI Blog (16 March 2015) <https:// delilawblog.wordpress.com/2015/03/16/andres-delgado-casteleiro-opinion-115-concerning-thescope-of-the-new-exclusive-competence-on-foreign-direct-investment $>$ accessed 9 February 2016.

Dimopoulos, A.,EU Foreign Investment Law (Oxford University Press 2011).

Dimopoulos, A., 'The Involvement of the EU in Investor-State Dispute Settlement: a Question of Responsibilities' (2014) 51 Common Market Law Review 1671-1720.

Dolzer, R. and Schreuer, C., Principles of international investment Law (2nd edn, Oxford University Press 2012).

González-Bueno, C. and Lozanoon, L., 'More Than a Friend of the Court: The Evolving Role of the European Commission in Investor-State Arbitration',Kluwer Arbitration Blog (26 January 2015) $<$ http://kluwerarbitrationblog.com/2015/01/26/more-than-a-friend-of-the-court-the-evolving-roleof-the-european-commission-in-investor-state-arbitration> accessed 9 February 2016.

Hindelang, S., 'Circumventing Primacy of EU Law and the CJEU's Judicial Monopoly by Resorting to Dispute Resolution Mechanisms provided for in Inter-se Treaties?' (2012) 39 Legal Issues of Economic Integration 179-206.

Hoffmeister, F., 'Litigating against the European Union and Its Member States - Who Responds under the ILC's Draft Articles on International Responsibility of International Organizations?' (2010) 21 European Journal of International Law 723-747.

Hoffmeister, F., 'The European Union and the Peaceful Settlement of International Disputes' (2012)] 11 Chinese Journal of International Law 77-105.

Juillard, P., 'L'évolution des sources du droit des investissements' (1994) 250 Recueil des cours 9-216.

Kleinheisterkamp, J., 'Financial Responsibility in the European International Investment Policy' (2014) 63 The International and Comparative Law Quarterly 449-476.

Kuijper, P.J., 'International Responsibility for EU Mixed Agreements', in C Hillion and P Koutrakos (eds), Mixed Agreements Revisited: The EU and its Member States in the World (Hart Publishing 2010) 208-228.

Lavranos, N., 'New Developments in the Interaction between International Investment Law and EU Law' (2010) 9 The Law and Practice of International Courts and Tribunals 409-441.

Peterson, L.E., 'European Commission's DG Trade tries to intervene for first time in an extra-EU BIT case to offer "systemic" views, but ill-timed application is rejected', IA Reporter (9 July 2014a) $<$ http://www.iareporter.com> accessed 9 February 2016.

Peterson, L.E., 'Brussels' Latest Intervention Casts Shadow over Investment Treaty Arbitrations Brought by Jilted Solar Energy Investors',IA Reporter (8 September 2014b) <http://www. iareporter.com> accessed 9 February 2016.

Reinisch, A., 'The EU on the Investment Path, Quo Vadis Europe - The Future of EU BITs and Other Investment Agreements' (2014) 12 Santa Clara Journal of International Law 111-157.

RigoSureda, A., 'Precedent in Investment Treaty Arbitration' in C Binder, U Kriebaum, A Reinisch and S Wittich (eds),International Investment Law for the 21st Century: Essays in Honour of Christoph Schreuer (Oxford University Press 2009) 830-842.

Rosas, A., 'International Dispute Settlement: EU Practices and Procedures' (2003) 46 German Yearbook of International Law 284-322.

Salacuse, J.W., The Law of Investment Treaties (Oxford University Press 2010).

Sornarajah, M., The International Law on Foreign Investment (Cambridge University Press 2004).

Stumer, A., 'Liability of Member States for Acts of International Organizations: Reconsidering the Policy Objections' (2007) 48 Harvard International Law Journal 553-580.

Tietje, C., 'The Applicability of the Energy Charter Treaty in ICSID Arbitration of EU Nationals vs. EU Member States' (2009) 1 Transnational Dispute Management 5-18.

Tietje, C., Sipiorski, E. and Töpfer, G., 'Responsibility in Investor-State Arbitration in the EU. Managing Financial Responsibility Linked to Investor-State Dispute Settlement Tribunals Established by EU's International Investment Agreements' (December 2012) Directorate-General for External Policies of the Union. Study EXPO/B/INTA/FWC/2009-01/Lot 7/31.

Titi, C., 'International Investment Law and the European Union: Towards a New Generation of International Investment Agreements' (2015) 26 European Journal of International Law 639-661. 